\title{
Hypoxia potentiates cytotoxicity of LPS-activated microglial BV2 cells in vitro by synergistic effects on cytokine and nitric oxide secretion
}

Susan Jung,, Affl

Corresponding Affiliation: Aff1

Daniel Frey, $\underline{\text { Affl }}$

Florian Brackmann, $\frac{\text { Affl }}{\text {. }}$

Mandy Richter-Kraus, $\stackrel{\text { Affl }}{\text { An }}$

Regina Trollmann, $\frac{\text { Affl }}{\text { f }}$

ArticleInfo

\begin{tabular}{|c|c|c|}
\hline \multicolumn{3}{|r|}{ ArticleInfo } \\
\hline ArticleID & $:$ & 60 \\
\hline ArticleDOI & $:$ & 10.1186/2194-7791-2-S1-A20 \\
\hline ArticleCitationID & $:$ & A20 \\
\hline ArticleSequenceNumber & $:$ & 20 \\
\hline ArticleCategory & $:$ & Meeting abstract \\
\hline ArticleFirstPage & $:$ & 1 \\
\hline ArticleLastPage & $:$ & 2 \\
\hline ArticleHistory & : & $\begin{array}{ll}\text { RegistrationDate } & : 2015-7-1 \\
\text { OnlineDate } & : 2015-7-1\end{array}$ \\
\hline ArticleCopyright & $:$ & $\begin{array}{l}\text { Jung et al.2015 } \\
\text { This article is published under license to BioMed Central } \\
\text { Ltd. This is an Open Access article distributed under the } \\
\text { terms of the Creative Commons Attribution License } \\
\text { (http://creativecommons.org/licenses/by/4.0), which permits } \\
\text { unrestricted use, distribution, and reproduction in any } \\
\text { medium, provided the original work is properly cited. }\end{array}$ \\
\hline
\end{tabular}

Aff1

Department of Pediatrics, Neuropediatrics, Friedrich-Alexander University Erlangen-Nuremberg, Germany

Abstracts of the 51st Workshop for Pediatric Research

51st Workshop for Pediatric Research

Göttingen, Germany

16-17 April 2015

This supplement has not been sponsored.

Meeting abstracts 


\section{Background}

Microglial activation due to a variety of stimuli results in secretion of high levels of neurotoxic substances including pro-inflammatory cytokines, nitric oxide (NO), and reactive oxygen species. Clinical studies indicate a crosslink between inflammatory and hypoxia-regulated pathways suggesting that bacterial infections may sensitize the immature brain to hypoxic injury.

\section{Methods}

BV2 cells were exposed to lipopolysaccharides (LPS, $1 \times 10^{5} \mathrm{EU} / \mathrm{ml}$ for $\left.24 \mathrm{~h}\right)$ and hypoxia $\left(1 \% \mathrm{O}_{2}\right.$ for $\left.6 \mathrm{~h}\right)$. Cytokine and NO release was quantified by ELISA and the Griess reaction, respectively. Cytotoxicity was determined in MTS cell viability assays.

\section{Results}

Activation of BV2 microglial cells by LPS exposure stimulated significant and persistent production of NO, IL-1 $\beta$, IL-6, and TNF- $\alpha$. Even after LPS removal, ongoing NO and cytokine secretion could be observed. While hypoxia alone mediated exclusively a significant, short-term increase of IL-1 $\beta$, oxygen deprivation enhanced LPS-induced secretion of NO, IL-1 $\beta$, IL-6, and TNF- $\alpha$ significantly. Surprisingly, pre-stimulation of BV2 cells by hypoxia prior LPS exposure abolished microglial activation suppressing LPS-induced NO production. Hereby, cell-free supernatants derived from LPS-activated microglial cells exhibited a stronger cytotoxic effect in glial and neuronal cells than LPS exposition per se $(\mathrm{P}<0.001)$. Again, hypoxia potentiated LPS-induced cytotoxicity.

\section{Conclusion}

Present data prove that i) the outcome of hypoxia is determined by the microglial activation status and that ii) LPS-induced soluble factors rather than LPS are mediators of microglial neurotoxicity under conditions of hypoxia in vitro. Activation of pro-inflammatory pathways may sensitize microglial cells to promote hypoxia-induced injury of the developing brain. Consequently, our findings may promote neuroprotective therapeutic strategies in the field of perinatal brain injury. 